\title{
An Inquiry on the Affordability of Legal Services and the Appropriateness of the Regular Courts for Consumer Redress in Nigeria
}

\author{
Dahiru Jafaru Usman', Nurli Yaacob², Aspalella A. Rahman ${ }^{2}$ \\ ${ }^{1}$ Department of Public Law, Faculty of Law, Bayero University Kano, Kano, Nigeria \\ ${ }^{2}$ School of Law, Universiti Utara Malaysia, Sintok, Kedah, Darul Aman, Malaysia \\ Email: djafaru@gmail.com, nurli@uum.edu.my, lella@umm.edu.my
}

Received 19 March 2016; accepted 7 May 2016; published 10 May 2016

Copyright (C) 2016 by authors and Scientific Research Publishing Inc.

This work is licensed under the Creative Commons Attribution International License (CC BY).

http://creativecommons.org/licenses/by/4.0/

(c) (i) Open Access

\begin{abstract}
The paper assessed the appropriateness of the regular courts for consumer redress in Nigeria in view of delays, and the cost of legal services before the ordinary courts. The paper adopted a phenomenological qualitative research approach in exploring the perspectives and experience of government officials and other private bodies involved in consumer protection and consumer redress. Twenty face-to-face interviews were conducted, transcribed and thematically analysed. The study found that legal services are not affordable to the consumers and that the ordinary courts are inappropriate for consumer dispute resolution. The research participants were limited to officials of consumer protection, products standard setting agencies, legal aid, academics, and heads of consumer organizations. The participants excluded the ordinary consumer of goods and services in the country. The study recommends the establishment of a cheap, simple and expeditious redress mechanism for redressing the widespread consumer injustice in the country. A wellfunded legal aid scheme to bridge the gap between the poor consumer and the justice system is equally suggested. This study is the first attempt at qualitatively exploring in-depth the appropriateness of the justice delivery system for consumer redress in Nigeria.
\end{abstract}

\section{Keywords}

Redress, Consumer Access to Justice, Affordability of Legal Services, Nigerian Judicial System, Delay 


\section{Introduction}

Justice according to Rawls (Rawls, 1999: p. 3) "is the first virtue of social institutions”. The pursuit of justice according to Davis, Fisher, Hetherington and Pollock (2014) is the heart of the legal profession (Davis et al., 2014). Justice is fundamental when wrongs are committed, and access to it is vital in building just and fair societies (Olajide, 2013). The right to redress is a consumer right declared by both President J.F. Kennedy in the President's message to the US Congress and the 1985 United Nations Guidelines for Consumer Protection (Borna, 1989). Access to justice is a fundamental right without which the enforceability of other rights becomes illusory (Cranston, 1979). In fact, access to justice has been considered as one of the best privileges of citizenship (van Aggelen, 2013). The provision of cheap, simple, and expeditious mechanism for such justice delivery is one of the sure ways through which citizens as consumers can right consumer injustices. Justice denial has implication on the democratic credentials of countries. Although provisions and judicial authorities (such as the US Supreme Court case of Gideon v. Wainwright) abound on the need for access to justice in criminal spheres, same is not the case in respect of the civil legal needs of the populace that are as compelling and important as the protection of the liberty of accused persons (Agrast, 2014; Davis et al., 2014). In fact, there is access to justice crisis in the both developing and developed world especially for the enforcement of civil rights (Lippman, 2014; Rhode et al., 2014; Barton, 2015; Davis et al., 2014; Lynch, 2015; Lash, Gee, \& Zelon, 2015). Davis et al. and Lynch report that millions of Americans lack representation in civil cases that includes consumer disputes annually (Lash, Gee, \& Zelon, 2015; Davis et al., 2014). According to Cooper, access to US justice system "remains an embarrassing problem”, (Cooper, 2015: p. 205).

The implication of the access to justice crisis on consumer protection is an ongoing debate (Yuthayotin, 2015a; Barton, 2015). Prohibitive, staggering and high attorneys' and court fees have been identified as the greatest barriers against consumer access to justice in the US and other jurisdictions (Liao, 2014; Maggs, 1990; Hodges, 2012; Axworhty, 1976; Green, 1974; Northwestern University School of Law, 1975). The ordinary courts are expensive, cumbersome and slow, and resources needed to obtain redress before these courts (Cranston, 1979; Stuhmcke, 2002; Liao, 2014). In the words of Jones and Boyer, there is a "lingering, rankling sense of frustration experienced by the consumers who feel they have been cheated, but realize that justice is priced beyond their means”, (Jones \& Boyer, 1971). These frustrations have been found to be among the major causes of civil disruption, revolts and urban riots in places such as the US (NACCD, 1968). In Bangladesh, Mollah identified delays as "crucial problems" affecting the powers of Bangladesh courts in justice delivery (Mollah, 2014: p. 487). Methodologically, cited works of scholars such as Maggs and Mollah differ from the current study. Whereas both Maggs and Mollah did not rely on any empirical data, this study was primarily based on qualitative data collected through interviews. This is because cost and delays as twin problems for consumer redress have not been explored especially in developing countries such as Nigeria. This research being qualitative contributes in that regard.

Access to justice means the right to ventilate grievances unhindered. In consumer terms, access to redress is vital in improving consumer confidence and in shaping consumer purchasing decisions (Gibson, 1992). On egalitarian basis access to the court should not depend on status or means. Unfortunately, access to court is only affordable to the rich (Lippman, 2014; Gibson, 1992; OFT, 1991). Across jurisdictions justice especially where it involves consumer disputes is highly expensive (Hawes, 1989; Maggs, 1990). The ignorance of most consumers of their rights and lack of consumer activism across jurisdiction also militate against consumer access to justice (Goldring, 1978). In other words, studies across jurisdictions found the culture of under-reporting of consumer wrongs and consumer reluctance in pursuing their rights (Vidmar, 1988; Samuels \& Vidman, 1986). Even in developed jurisdictions evidence abound that only an insignificant proportion of consumer grievance reaches the court or are ventilated before other redress mechanisms (Gibson, 1992; Schmitz, 2013; Fitzpatrick, 1992; L'Heureux, 1992; Best \& Andreasen, 1977). This reluctance and culture of under-reporting of consumer wrongs have not been empirically explored in the context of Nigeria. This study contributes in that regard.

According to Creutzfeldt and Khanna et al., consumer dispute resolution is one of the under-explored areas in the consumer protection literature (Creutzfeldt, 2014; Khanna et al., 2015). Although access to justice crisis is global (Lippman, 2014), the Nigerian case is worrisome and is the concern of this paper. Delays, cost of lawyers' service and the cost of litigating dispute before ordinary courts are the twin barriers against consumers access to justice in Nigeria. According to statistics, over a hundred million Nigerians lack access to justice and representation (Igbintade, 2013; Watch, 2006). Access to justice is a big problem in the country. Owners of legal rights are scared to approach the courts for redress because of the cost and the inordinate delays. Even those who summon 
the courage to approach the courts may not get the redress in their lifetime as cases span in some occasions for over three decades to be finally decided (Olajide, 2013; Adesomoju, 2015). Access to justice crisis in Nigeria is largely attributable to the cumbersome nature of the judicial system, the cost, and the poverty in the country (Onuba, 2012; Olatunji, 2015; Ibrahim, 2012). Recently, the Vice President of Nigeria put the figures of the Nigerian population living below the poverty line at 63\% (Olatunji, 2015; Mutasa \& Paterson, 2015). This is startling. Although for decades legal aid scheme was one of the palliative measures initiated to cushion the rising access to justice crisis, evidence shows that legal aid funding globally has plummeted (Lash, Gee, \& Zelon, 2015; Olatunji, 2015; Ibrahim, 2012; Lippman, 2014; Pointing, 2015). Nigeria is not an exception. The legal aid scheme is underfunded and understaffed (Igbintade, 2013) thereby compounding the problem. It is important that consumers are provided with cheap, simple and quick dispute resolution forum. The perspectives, experience and understanding of the stakeholders in justice delivery on the affordability of legal services and consumer redress, is less understood and unexplored (Creutzfeldt, 2014). Although literature abounds on the crisis of access to justice globally, no study applied the global frameworks and evidence from different jurisdictions as lessons in analyzing the current state of access to justice in Nigeria. This study seeks to fill this gap by gaining an in-depth understanding of the perspectives of stakeholders in the Nigerian justice delivery system. Specifically, the study seeks an in-depth understanding whether the poor consumer can afford legal services, as well as the appropriateness of the ordinary court for consumer redress.

\section{Methods}

\subsection{Design}

The research approach is qualitative. It is exploratory and descriptive. The choice of the approach is justified as it enables the researchers gain in-depth understanding of the perspectives of stakeholders on the phenomenon of research (Schurink et al., 2011). The researchers had an in-depth understanding of the justice delivery system as it relates to consumer redress from the participants' world-views. To ensure variation in the participants' experience and perspective on the phenomena of the research, the study was conducted with the relevant stakeholders involved in consumer justice delivery across Nigeria.

\subsection{Population and Sampling}

The study employed the purposive sampling technique in recruiting twenty participants. The choice of the participants was limited to individuals with the needed information to meet the research objectives as recommended by Drew (2014) and Neuman and Robson (2004). These include staff of the Legal Aid Council of Nigeria (LACON), Consumer Protection Council (CPC), Standard Organization of Nigeria (SON), lawyers in practice, academia, staff in the licensing and consumer protection units of some deregulated sectors such as electricity, telecommunications, and consumer representatives. The selection of CPC was because it is the apex consumer protection body while exclusive competence on products standards was the basis for choosing the SON. The deregulated electricity and telecommunications sectors were chosen because all Nigerians are consumers of both directly or indirectly.

For ethical reasons, the participants' consent to participate in the research and to be audio taped was sought before the commencement of the interview. Participants were guaranteed the confidentiality of their details and the freedom to withdraw their consent at any stage of the interview.

\subsection{Data Collection and Management}

The individual face-to-face in-depth interview was the data collection method. The semi-structured interview (SSI) pattern was utilized. The SSI was adopted because it is flexible and enables the researchers to formulate sets of pre-determined questions in advance and probing techniques employed based on the participant's responses (Gray, 2004). The participants' convenience determined the scheduling of the interviews. The interviews lasted between forty-five minutes to one hour. The interviews focused on administration of justice and consumer redress and participants were told that no answers to questions asked were right or wrong. Guiding questions included: "How do you assess the speed and affordability of the justice institutions to the poor?" "In your opinion is the judicial system appropriate for consumer redress?” There were series of follow-up questions arising from the initial questions and the participants' responses. During the interviews, there was more of listening and 
probing, and clarification offered (where necessary) to ensure participants’ understanding (Schurink et al., 2011). The interviews were in English, recorded and transcribed verbatim by the corresponding author. To avoid loss and for confidentiality purposes, the transcribed data were saved on a flash drive and other secure places. The transcripts were later printed for ease of analysis.

\subsection{Data Analysis}

The data analysis as suggested by scholars such as Rapley, and Maxwell was conducted concurrently with the data collection. The data was manually managed and its analysis thematically conducted (Maxwell, 2005; Rapley, 2004). The value and theoretical flexibility of the thematic analysis (TMA) justified its adoption (Braun \& Clarke, 2006; Clarke \& Braun, 2013). TMA involves searching important themes from the data to explain the research phenomenon (Fereday \& Muir-Cochrane, 2008; Daly, Kellehear, \& Gliksman, 1997; Clarke \& Braun, 2013). According to Braun and Clarke (2006: p. 78), TMA “provides a flexible and useful tool, which can potentially provide a rich and detailed, yet complex account of data”. In fact, TMA is considered as the foundation of all qualitative data analysis methods (Braun \& Clarke, 2006). Through the TMA, this study identified and reported the perception, understandings and experience of the participants in the form of themes and sub-themes. The analysis followed Braun and Clarke's (2006) six phases of thematic analysis (Braun \& Clarke, 2006) (Table 1). The reading of the interview transcripts was recursive. The study employed an inductive approach as such the transcripts were carefully and repeatedly read to gain deeper an overall appreciation of the phenomenon jotting down the themes emerging from the participants' responses (Aronson, 1994; Fereday \& Muir-Cochrane, 2008; Rice \& Ezzy, 1999). This process enabled the researchers to gain deeper understanding of the research participants' world.

In other words, the data was coded and categorized, and themes and sub-themes developed. The major themes developed were lack of affordability and slow judicial system. Sub-themes for these themes were identified from the data and presented in the results section. To ensure that the themes and sub-themes deduced from the interview were properly categorized and accurately represent the exact experience and perspectives of the participants, the researchers cross-checked and compared the themes from the listening of the audio and a thorough reading of the printed copies. For transparency and emphasis, direct quotes from the Participants' responses were included in the analysis.

\section{Findings}

Themes such as affordability of the court-related and legal practitioners' fees; delay in justice dispensation and the causes of delays emerged from the analysis of the interview transcripts. Lawyers' attitude in the prosecution of cases constitutes the main causes delaying cases before the ordinary courts.

\subsection{Affordability of Legal Services (Court-Related and Legal Practitioners' Fees)}

Like all organized societies, Nigeria has judicial structures for redressing injustice. The formal justice system

Table 1. Braun and Clarke’s six phases of qualitative data analysis.

\begin{tabular}{|c|c|c|}
\hline & Phases & Description of the process \\
\hline 1 & $\begin{array}{l}\text { Familiarising yourself } \\
\text { with your data: }\end{array}$ & Transcribing data (if necessary), reading and rereading the data, noting down initial ideas. \\
\hline 2 & $\begin{array}{l}\text { Generating initial } \\
\text { codes: }\end{array}$ & $\begin{array}{c}\text { Coding interesting features of the data in a systematic fashion across the entire data set, collating data } \\
\text { relevant to each code. }\end{array}$ \\
\hline 3 & Searching for themes: & Collating codes into potential themes, gathering all data relevant to each potential theme. \\
\hline 4 & Reviewing themes: & $\begin{array}{l}\text { Checking in the themes work in relation to the coded extracts (Level 1) and the entire data set (Level 2), } \\
\text { generating a thematic "map" of the analysis. }\end{array}$ \\
\hline 5 & $\begin{array}{l}\text { Defining and naming } \\
\text { themes: }\end{array}$ & $\begin{array}{l}\text { Ongoing analysis to refine the specifics of each theme, and the overall story the analysis tells; generating } \\
\text { clear definitions and names for each theme. }\end{array}$ \\
\hline 6 & Producing the report: & $\begin{array}{l}\text { The final opportunity for analysis. Selection of vivid, compelling extract examples, final analysis of } \\
\text { selected extracts, relating back of the analysis to the research question and literature, producing a } \\
\text { scholarly report of the analysis. }\end{array}$ \\
\hline
\end{tabular}

Source: (Braun \& Clarke, 2006). 
operates through the ordinary courts and remains largely the redress forum. The Majority of cases presented before the ordinary courts are settled through litigation (Onyema, 2013). Litigants must pay the necessary filing fees (that include the fees for the service of the processes on the defendant) before cases are accepted. Being lay people, most litigants need legal representation to appreciate the procedures and all the processes involved in the adjudication of their dispute. Hiring lawyers is something beyond majority who are poor and under too many pressures. The cost and expense is a barrier to accessing justice (Spiller \& Tokeley, 2010; Ramseyer, 2015; Larson, 2015). Some of the participants reported the cost and expense barriers. Participant 15 assertively stated that justice is "actually not affordable" to the poor Nigerians. In similar fashion Participant 4 while believing the justice system to be open stated that it is "not very affordable”. Participant 1 vividly captured the affordability crisis in the following words:

"most of them (Nigerians) cannot afford. To afford the services of a lawyer is not easy. Because nowadays, the cost of filing, the payment and settlement of fees for lawyers is not every Nigerian that can afford it. Seventy percent (70\%) of Nigerians cannot afford the services of a lawyer”.

Strengthening the position of Participant 1, Participant 6 equally reported that the cost of litigation comprising the court and lawyers' fees is "something the Nigerian poor masses cannot afford". It is this huge problem of affordability that the legal aid scheme was initiated. Accordingly, Participant 14 believes that the expensive nature of legal practice was what led to conceiving the idea of legal aid. Participant 14 stated that "legal practice is expensive. The sole aim of conceiving the legal aid was to see that the indigent have access to justice".

Participant 12 a senior officer of the Legal Aid Council of Nigeria reported the "crisis of means" facing poor Nigerians when it comes to access to justice. According to the Participant:

"When you look at most of the cases, we have around, it would actually tell you that honestly most Nigerians can't afford the private legal practitioners demand. When they (the masses) come here, they would tell you we don't have money to get a lawyer in fact we met a lawyer, and the money is too much we can’t afford it. We live in the rural areas, and we don't have much. We can't even afford to feed our family not to talk of getting a lawyer. So, I think looking at the private lawyers and the judicial system, honestly there are so many people out there who are in need of legal representation but can't afford it. It's really becoming worst every day. Most of the challenges have to do with money. Because for you to get a lawyer, in Nigeria, it means you have to be 'boxed up'. You have to have money. Because when you get to most of those chambers, it is just like in the hospitals. Before you see a lawyer, you pay for the opening of your file, you pay for consultation and every time the lawyer is going to court you must pay his appearance fees”.

\subsection{Delay in Justice Dispensation}

Section 36 of the Constitution Federal Republic of Nigeria, 1999 made speedy disposal of cases a human right. Although "speedy disposal of cases" was not used in the section, but the section mandates that in all suits for determination of civil rights of every person, the trial must be within reasonable time. Again though what is reasonable is hard to define the length cases take to be decided is a reason to scare Nigerians with genuine grievances from approaching the courts. It has been empirically established that cases at times spend up to 29 years pending before the High Court in the country. This is attributable to the congestion and the slow nature of the justice delivery (Onyema, 2013). Participants reported the slow phase at which the Nigerian justice delivery system operates. Participant 15, for instance, reported that cases "take longer time” to be decided. Similarly, Participant 9 and 4 respectively believe "there are a lot of delays” and the judicial system is "not speedy”. Participant 9 believes that these delays discourage "the owner of a right or the beneficiary of the right from claiming it”. Assessing the speed at which cases are disposed of in our courts, Participant 2 a Professor of Law reported that the speed is "terribly poor. I mean terribly poor". The views of Participant 14 on the slow nature of our judicial system are equally instructive. Participant 14 reported that "when it has to do with speed, to be frank, our judicial system is very slow. This has to do with the congestion of matters in court".

On the discouraging effects of delays in the administration of justice, Participant 20 stated that:

“ $\{\mathrm{j}\}$ ustice delay is justice denied. Here in Nigeria you will file a case, at the end of the day in the process of finding a lawyer and the financial issues you end up being discouraged with the kinds of adjournments. The cost of having a lawyer is another issue. At the end of the day when you look at your problem, compare it 
with the time you will spend in going to court and the amount of money you spent you feel discouraged”.

The sub-themes related to speed and delays are bureaucratic bottlenecks and the cumbersomeness nature of the judicial system. Four of the Participants (1, 2, 7 and 8) described the judicial system in Nigeria as highly bureaucratic. These bureaucracies prevent litigants including lawyers with genuine grievances from accessing justice. Participant 2 reported that:

“ $\{\mathrm{m}\}$ yself as a lawyer because of the problems associated with the judicial system, the cost, the bureaucracy, the logistics, the frustrations, would not be interested in pursuing my consumer rights".

These bureaucracies are problems to the consumers. The bureaucracies have complicated the plights of ordinary Nigerians in the area of accessing justice. Capturing the problem, Participant 1 reported that:

"there are so many bottlenecks especially at the State High Courts. The procedures are not known to ordinary citizens, or the citizens cannot access the services without use of lawyers which is also hindering the transparency and speedy dispensation of civil issues".

Participant 7 is more vivid on the bureaucratic bottlenecks and the cumbersomeness associated with the Nigerian judicial system. In fact, the Participant hopes and urges reforms. It is the Participant's view that:

“ $\{$ p\}ersonally, Nigerian judicial system with all due respect is very, very bureaucratic. It does not serve the common man; it does not reach out to peoples' right, and it is a reflection of our society if you can argue that. We are still a developing country, so I still hold hope that it would reform, but the truth is that Nigeria's judicial system has huge bottlenecks, huge red tape, it is sad, and it is an aberration. The whole reason it is in place is to protect people, to protect laws and to guide the society. It is sad that it is this bureaucratic and cumbersome".

Further on cumbersome nature of the judicial system as a sub-theme under delay in justice dispensation, Participant 6 reported that:

"Nigerian judicial system is cumbersome. Something we inherited from the colonial masters and is not fit for our country, for our people, our system and lifestyle. What I think of the Nigerian judicial system is that there should be a sort of reformation, a set of reforms to radically divorce from the colonial procedures. When we do that we would be able to fast track our proceedings to cater for the needs of our people. And also another thing is the issue of whether there should be recognition of class action. So, if that would also be accommodated in our judicial system then definitely this would assist in no small measure”.

\subsection{Causes of the Delays in the Judicial System}

Although the delays associated with the Nigerian judicial system is attributable to several factors such as the complexities of cases, the nature of evidence required to prove a claim, and the "Nigerian factor", lawyers are believed to be contributors to these delays (Olajide, 2013). Part of the blame heaped on lawyers is in filing frivolous applications and seeking unnecessary adjournments for matters that could be dispensed with easily. According to Participant 13:

"if you go to court you see that some of the problems or most of the problems are from the lawyers handling the cases. On a frivolous reason, a lawyer would just ask for an adjournment. This adjournment the court would give some months. So these are some of the issues. There are a lot of factors. Sometimes the nature of the evidence, and the complexity of the matters. Nobody is saying that it is good".

Other participants equally attribute the delays to the attitude of lawyers who prosecute the cases before the ordinary courts. In blaming lawyers, Participant 17 stated that:

"you go to court, and you see either a lawyer not coming to court or a lawyer not getting prepared for his case and applying for an adjournment for no good cause. It is not good for the litigants. Because the litigant is the one that bears the cost and the psychological trauma the litigants pass through in the cause of constant adjournment. It makes them lose faith in the whole judicial system which is not quite good. I think we need some kinds of improvement".

On the "Nigerian factor" as a contributor to the crisis of delay, Participant 10 reported that in his opinion 
“Nigerian factor is responsible for whatever shortcoming we see in the judicial system”.

\section{Discussions}

\subsection{Affordability of Legal Services to the Nigerians as Consumers?}

This study reveals that lawyers' service, as well as court-related fees, are expensive and beyond the poor consumer. The research findings on cost and expense of legal services and court related fees are similar to previous studies (Davis et al., 2014; Willet \& Oughton, 2010; Maggs, 1990; CCE, 2008). This expensive judicial system thrives in Nigeria despite the poverty rate in the country where a greater part of the population lives below 1 USD per day (Aliyu, Dada, \& Adam, 2015; Iwayemi, 2008; WB, 2013). Although inability to afford legal services is a problem to several millions of people even in the US (Lippman, 2014; Davis et al., 2014), considering the poverty rate in Nigeria, it is safe to argue that the poor consumers cannot afford these expensive legal services and court related fees. These add to the barriers preventing consumers from getting justice. Legal representation improves the efficiency of courts in justice delivery and has been held to be one sure way of delivering equal justice to consumers as citizens (Lippman, 2014; Davis et al., 2014). But Nigerians lack representation for redressing civil claims such as consumer casesdue to the cost of litigation. They therefore, lack access to justice compared to the powerful merchants and the rich class. This is contrary to the Fundamental Objectives and Directive Principles of State Policy contained under section 14 (1) of Chapter two of the Nigeria's Constitution (CFRN, 1999).

\subsection{Are the Ordinary Courts in Nigeria Appropriate for Consumer Redress?}

The participants' responses confirm that the Nigerian judicial system is cumbersome, slow, and bureaucratic with unbearable cost for litigants. The findings are similar to previous studies such as Kakalik et al. and Silver (Kakalik et al., 1996). With the stated characteristics, the system it is submitted is inappropriate for consumer redress. The principal reason is that consumer disputes require expeditious disposal. The need for expeditious disposal of consumer complaints has been recognized by the highest consumer protection statute in the country, the Consumer Protection Council Act (CPC Act). The CPC Act made speedy disposal of consumer complaints first priority among the functions for which the CPC was established. Section 2 (a) of the CPC Act provides that;

“The Council shall-(a) provide speedy redress to consumers' complaints through negotiation, mediation, and conciliation”.

Participant 20 spoke on the inappropriateness of the court system for consumer redress. Asked on how appropriate he considers the court system for consumer redress, the Participant responded;

"No, it is not. It is not appropriate because when a consumer brings a problem, he brings this problem because he buys a product and the product fails because it is substandard or fake. He needs immediate refund or replacement because when you buy a product you want to use it immediately. And when you end up having this problem and you end up in court, before the court judges (sic) this thing will take 5 - 6 months. At the end of the day what are you going to do with that products?”

Additionally, the audience granted to lawyers before the ordinary courts account for the inordinate delays and the other shortcomings of the judicial system. Most of the lawyers are more of technicalities than substantial justice. It is submitted that such system that accommodates lawyers is inappropriate for consumer redress. The jurisprudence on small claims or consumer courts (being consumers' best friend) are built around the prevention of lawyers from appearing before them (Eovaldi \& Gestrin, 1971). The exclusion of lawyers before the small courts was necessary if they are to function and to achieve the object behind the establishment of the small courts. This is because where lawyers are granted audience the purport for the establishment of the small claims court is often defeated (Liao, 2014; Eovaldi \& Gestrin, 1971). They bring to the small claims court technical justice abhorred by the jurisprudence of consumer redress.

The smallness of consumer claims is one of the most important justifications for the inappropriateness of the delay-prone and expensive ordinary courts (Hawes, 1989; L'Heureux, 1992; Hodges, 2014). It is very unwise ventilating small claims before expensive avenues such as the delays-prone and expensive ordinary courts in Nigeria (Goldring, 1978; Yuthayotin, 2015b; Coats, Gantz, \& Heathcotte, 1969; Lukonga, 2015; Green, 1974; 
Sand \& Weisberg, 1966; Cox, Peichl, \& Pestel, 2013). Unfortunately, no other avenue or arrangements exist within the judicial system to cater specifically for such small claims. Is there any respite for the consumers? Left with only the ordinary courts would poor consumers appreciate the meaning of access to redress? Alternatives or special procedural arrangements for consumer disputes within the ordinary courts system would serve useful purposes. These avenues or special arrangements must, however, be cheap, inexpensive and simple in view of the smallness of consumer claims. Such avenues should be designed to accommodate waivers of filing fees and procedural technicalities. This is the place of the small claims court and simple procedures which it is argued are more befitting for redressing consumer injustice. According to Participant 15, the small claims court "would go a long way in settling most of the disputes we have. The small claims court is devoid of all the legal technicalities and less cumbersome. It is a straight forward kind of thing. I think there is a need to have a tribunal instead of going to the regular courts”.

Some of the participants opined that separate avenues for consumer grievance handling outside the delayprone and congested ordinary courts would improve access to justice for the poor Nigerian consumers. According to Participant 3, "the establishment of consumer court would be the best". In fact, Participants 4, 7 and 15 respectively see the establishment of small claims court as “excellent”, useful”, "relevant”, and a "fantastic” idea. Participant 4 however added the need for consumer enlightenment in that regards. On the issue, Participant 4 said that:

“This is excellent. However, if you establish any court or any tribunal, there must be awareness, popular awareness. And this awareness should be done by a dedicated rights organization”.

Participant 6 was specific on the establishment of separate tribunals outside the regular courts for consumer redress. According to the Participant:

"I would rather suggest a separate tribunal or separate rules guiding its proceedings to fast track any issue of consumer case. Just like we have the issue of election tribunals, to make them time bound. So, any case would start from this time and end up at this time. And if we have to take a consumer protection case to our normal court then, we need to have practice direction that would ensure fast tracking such case to the end without any delay. So we have to detach it from our normal rules of court, normal procedure or civil proceedings or criminal proceedings rules. Then the issue of rigors of the proceedings, the processes that would not be easy for any Nigerian mass to be able to afford. So this is one of the problems”.

\section{Implications of Findings and Limitation of the Research}

The findings of this exploratory study can be used in setting policy agenda for legal aid, judicial reform and consumer justice administration. The findings would equally assist the private legal practitioners in the assessment of their pro-bono service to the poor consumers whose claims are often too small but in cumulative sense huge. This will prevent business enterprises from exploiting and profiting illegally from consumers through fraudulent and unfair marketing practices.

Consumer redress needs enhancement through the creation of alternatives to the ordinary courts. This is necessary to ensure justice in business relationships between the weak and poor consumers, and the unequal suppliers of goods and services providers. Consumer or small claims courts are suggested. This would increase consumer access to redress.

The research is however limited as the participants' sample was restricted to elites in the business, government circles and organized consumer representative who handle most of the consumer grievances. The findings, therefore, suggest that the ordinary consumers should be involved in future studies for a comprehensive picture of the affordability of legal services and appropriateness of regular courts for consumer redress. For generalizability, future research could quantitatively measure the affordability of legal services and appropriateness of regular courts for consumer redress using a large sample of both the elites and the consumers.

\section{Conclusion}

The study findings confirmed previous studies on the global access to justice crisis. Previous studies found access to justice a myth for the poor. The study findings indicate that the wheel of justice grinds slowly in the Nigerian courts and that "lawyer and court cost barriers" inhibit Nigerians who are all consumers from getting 
justice. Legal services and court fees are not affordable to Nigerians as consumers. It is sheer unfairness for a consumer with genuine grievance to be barred from taking advantage of a judicial system funded from his tax for reasons of cost (Jones \& Boyer, 1971). Cost and delays inhibit access to redress. This research, therefore, suggests that Nigerian consumers require a medium that is cheap, simple and expeditious for redressing their grievances. This is a government's responsibility. The smallness of consumer claims justifies their inexpensive and expeditious disposal. It is unwise to redress such claims before the expensive ordinary court. This study argues for the establishment of these avenues. Alternatively, specific Practice Direction for the hearing of consumer claims within the ordinary courts system would serve the consumer interest. The delays, congestion, and expense, are at the consumers' detriment and "a right is only as strong as the remedy available to enforce it", (Ramsay, 1981) (Ontario Law Reform Commission 1979 cited in Ramsay, 1981: p. 23). Business cashed on these setbacks in the judicial system to exploit consumers without the fear of being sued by the poor consumers battling with the harsh economic conditions in the country (Willet \& Oughton, 2010; Schmitz, 2013). As rightly observed and reported by the participants, for consumer to have justice, small claims court is long overdue and the state has a duty in this regard. According to Justice Aniagolu of the Nigerian Supreme Court in Ariori V. Elemo (1983) 1 S.C. N.L.R. 1, at 28;

"a state exists to do justice- justice to the state and justice to the citizens. The doing of justice is an obligation which the state owes to its citizenry and which it exercises principally through... the judiciary”.

The Learned Justice continued

“... fair hearing, of which speedy trial is one of the factors that go to make it fair, is therefore, in my view, a right involving the public policy that judiciary proceedings shall not fall below a certain standard, namely, a standard that trial of cases must be fair".

From the court's pronouncements, speedy disposal of cases counts in making hearing of cases fair. Allowing the hearing of consumer disputes before the delay-prone ordinary courts makes the hearing unfair. Nigerian consumers need justice for consumer wrongs, and this can only be guaranteed through cheap avenues that do not admit delays.

\section{References}

Adesomoju, A. (2015). Oil Spill: 32 Years after, S’Court Orders Shell to Pay N30m Compensation. The Punch, 6 June.

Agrast, M. D. (2014). World Justice Project Rule of Law Index 2014. http://worldjusticeproject

Aliyu, A. S., Dada, J. O., \& Adam, I. K. (2015). Current Status and Future Prospects of Renewable Energy in Nigeria. Renewable and Sustainable Energy Reviews, 48, 336-346. http://dx.doi.org/10.1016/j.rser.2015.03.098

Aronson, J. (1994). A Pragmatic View of Thematic Analysis. The Qualitative Report, 2, 1-3.

Axworhty, C. S. (1976). Controlling the Abuse of Small Claims Courts. McGill LJ, 22. Hein Online: 480.

Barton, B. H. (2015). Middle Income Access to Justice. In M. Trebilcock, A. Duggan, \& L. Sossin (Eds.), University of Toronto Law Journal, July, University of Toronto Press, 1-11.

Best, A., \& Andreasen, A. R. (1977). Consumer Response to Unsatisfactory Purchases: A Survey of Perceiving Defects, Voicing Complaints, and Obtaining Redress. Law \& Society Review, 11, 701-742. http://dx.doi.org/10.2307/3053179

Borna, S. (1989). Illegal Products and the Question of Consumer Redress. Journal of Business Ethics, 8, 499-505. http://dx.doi.org/10.1007/BF00381817

Braun, V., \& Clarke, V. (2006). Using Thematic Analysis in Psychology. Qualitative Research in Psychology, 3, 77-101. http://dx.doi.org/10.1191/1478088706qp063oa

CCE (2008). Green Paper on Consumer Collective Redress.

CFRN (1999). Constitution Federal Republic of Nigeria, Cap C25, Laws of the Federation of Nigeria.

Clarke, V., \& Braun, V. (2013). Teaching Thematic Analysis: Overcoming Challenges and Developing Strategies for Effective Learning. The Psychologist, 26, 120-123.

Coats, D., Gantz, C., \& Heathcotte, B. (1969). Small Claims in Indiana. Indiana Legal Forum, 3, 517.

Cooper, B. P. (2015). Access to Justice without Lawyers. Akron Law Review, 47, 10.

Cox, M., Peichl, A., \& Pestel, N. (2013). Labor Demand Effects of Rising Electricity Prices: Labor Demand Effects of Rising Electricity Prices: Evidence for Germany. IZA Policy Paper No. 74. 
Cranston, R. (1979). Access to Justice for Consumers: A Perspective from Common Law Countries. Zeitschrift Für Verbraucherpolitik, 3, 291-299. http://dx.doi.org/10.1007/bf02386022

Creutzfeldt, N. (2014). How Important Is Procedural Justice for Consumer Dispute Resolution? A Case Study of an Ombudsman Model for European Consumers. Journal of Consumer Policy, 37, 527-546. http://dx.doi.org/10.1007/s10603-014-9269-x

Daly, J., Kellehear, A., \& Gliksman, M. (1997). The Public Health Researcher: A Methodological Approach. Melbourne: Oxford University Press.

Davis, M. F., Fisher, F., Hetherington, B. D., \& Pollock, J. (2014). Transcript: Why We Need a Counsel in Civil Matters Where Basic Human Needs Are at Stake. Syracuse Law Review, 64, 369.

Drew, H. (2014). Overcoming Barriers: Qualitative Interviews with German Elites. The Electronic Journal of Business Research Methods, 12, 77-86.

Eovaldi, T. L., \& Gestrin, J. E. (1971). Justice for Consumers: The Mechanisms of Redress. Northwestern University Law Review, 66, 281-323. http://heinonline.org/HOL/LandingPage?handle=hein.journals/illlr66\&div=20\&id=\&page

Fereday, J., \& Muir-Cochrane, E. (2008). Demonstrating Rigor Using Thematic Analysis: A Hybrid Approach of Inductive and Deductive Coding and Theme Development. International Journal of Qualitative Methods, 5, 80-92.

Fitzpatrick, P. (1992). The Mythology of Modern Law. Hove: Psychology Press. http://dx.doi.org/10.4324/9780203308943

Gibson, L. (1992). Access to Justice and Consumer Redress within a Single Market. Journal of Consumer Policy, 15, 407-415. http://dx.doi.org/10.1007/BF01014119

Goldring, J. (1978). Public Law, Private Law, and Consumers’ Remedies. The Australian Quarterly, 50, 58-66. http://dx.doi.org/10.2307/20634980

Gray, D. E. (2004). Doing Research in the Real World. Thousand Oaks, CA: Sage.

Green, M. J. (1974). Appropriateness and Responsiveness: Can the Government Protect the Consumer? Journal of Economic Issues, 8, 309-328.

Hawes, C. (1989). Functioning and Reforms of Small Claims Tribunals in New Zealand. Journal of Consumer Policy, 12, 71-94. http://dx.doi.org/10.1007/BF00411390

Hodges, C. (2012). Current Discussions on Consumer Redress: Collective Redress and ADR. ERA Forum, 13, 11-33. http://dx.doi.org/10.1007/s12027-011-0245-5

Hodges, C. (2014). Consumer Redress: Ideology and Empiricism. In K. Purnhagen, \& P. Rott (Eds.), Varieties of European Economic Law and Regulation (Vol. 3, pp. 793-821). Cham: Springer International Publishing.

Ibrahim, O. R. (2012). 100m Nigerians in Absolute Poverty, Bureau Says. Daily Trust Newspaper.

Igbintade, W. (2013). About 100m Nigerians Don’t Have Access to Justice-Adelodun.

Iwayemi, A. (2008). Nigeria’s Dual Energy Problems: Policy Issues and Challenges. International Association for Energy Economics, 53, 17-21.

Jones, M. G., \& Boyer, B. B. (1971). Improving the Quality of Justice in the Marketplace: The Need for Better Consumer Remedies. The George Washington Law Review, 40, 357.

Kakalik, J. S., Dunworth, T., Hill, L. A., McCaffrey, D., \& Oshiro, M. (1996). Just, Speedy, and Inexpensive? An Evaluation of Judicial Case Management under the CJRA. DTIC Document.

Khanna, A., Singh, D., Swain, A. K., \& Narain, M. (2015). Transforming Electricity Governance in India: Has India’s Power Sector Regulation Enabled Consumers' Power?

L’Heureux, N. (1992). Effective Consumer Access to Justice: Class Actions. Journal of Consumer Policy, 15, 445-462. http://dx.doi.org/10.1007/BF01014122

Larson, D. A. (2015). Access to Justice. In J. Backhaus (Ed.), Encyclopedia of Law and Economics (pp. 1-7). New York: Springer. http://dx.doi.org/10.1007/978-1-4614-7883-6_570-1

Lash, K. A., Gee, P., \& Zelon, L. (2015). Equal Access to Civil Justice: Pursuing Solutions beyond the Legal Profession. Yale Law \& Policy Review, 17, 20.

Liao, Z. (2014). The Recent Amendment to China's Consumer Law: An Imperfect Improvement and Proposal for Future Changes. Beijing Law Review, 5, 163-171. http://dx.doi.org/10.4236/blr.2014.53016

Lippman, J. (2014). Brennan Lecture: The Judiciary as the Leader of the Access-to-Justice Revolution. NYU Law Review, 89, 1569-1902.

Lukonga, M. I. (2015). Islamic Finance, Consumer Protection, and Financial Stability. Washington DC: International Monetary Fund. http://dx.doi.org/10.5089/9781513515106.001

Lynch, B. L. (2015). Access to Legal Services in Rural Areas of the Northern Rockies: A Recommendation for Town Legal 
Centers. Indiana Law Journal, 90, 1683-1705.

Maggs, P. B. (1990). Access to Justice for the Consumer in the USA. Journal of Consumer Policy, 13, 65-78. http://dx.doi.org/10.1007/BF00411870

Maxwell, J. A. (2005). Qualitative Research Design: An Interactive Approach: An Interactive Approach (Vol. 41). Thousand Oaks, CA: Sage.

Mollah, A. H. (2014). Judicial Activism and Human Rights in Bangladesh: A Critique. International Journal of Law and Management, 56, 475-494.

Mutasa, C., \& Paterson, M. (2015). Africa and the Millennium Development Goals: Progress, Problems, and Prospects. Lanham, MD: Rowman \& Littlefield Publishers. https://books.google.com.my/books?id=VZbnCgAAQBAJ

NACCD (1968). Report of the National Advisory Commission on Civil Disorders.

Neuman, W. L., \& Robson, K. (2004). Basics of Social Research. Upper Saddle River, NJ: Pearson.

OFT (1991). Annual Report of the Director General of Fair Trading. London: OFT.

Olajide, O. A. (2013). Justice No Longer Lives in Our Court. http://dx.doi.org/10.2139/ssrn.2393565

Olatunji, D. (2015). Over 100m Nigerians Live below Poverty Line-VP Osinbajo. The Vanguard, 14 June.

Onuba, I. (2012). 112.5 Million Nigerians Live in Poverty-NBS. The Punch. http://www.punchng.com/business/business-economy/112-5-million-nigerians-live-in-poverty-nbs/

Onyema, E. (2013). The Multi-Door Court House (MDC) Scheme in Nigeria: A Case Study of the Lagos MDC. Apogee Journal of Business, Property \& Constitutional Law, 2, 96-130.

Pointing, J. (2015). Human Rights and the Criminal Justice System. By Anthony Amatrudo and Leslie William Blake (Routledge, 2014, 175pp. £80.00). British Journal of Criminology, 55, 1021-1023. http://dx.doi.org/10.1093/bjc/azv012

Ramsay, I. D. C. (1981). Consumer Redress Mechanisms for Poor-Quality and Defective Products. University of Toronto Law Journal, 31, 117-152. http://dx.doi.org/10.2307/825656

Ramseyer, J. M. (2015). Second-Best Justice: The Virtues of Japanese Private Law. Chicago, IL: University of Chicago Press. https://books.google.com.my/books?id=N1 YCgAAQBAJ http://dx.doi.org/10.7208/chicago/9780226282046.001.0001

Rapley, T. (2004). Interview. In C. Seale, G. Gobo, J. F. Gubrium, \& D. Silverman (Eds.), Qualitative Research Practice. London: Sage Publications.

Rawls, J. (1999). A Theory of Justice (Revised ed.). Oxford: Oxford University Press.

Rhode, D. L., Harvard, S., Review, L., \& Mar, N. (2014). Legal Scholarship. Harvard Law Review, 115, 1327-1361.

Rice, P. L., \& Ezzy, D. (1999). Qualitative Research Methods: A Health Focus. Melbourne: Oxford University Press.

Samuels, J., \& Vidman, N. (1986). Consumer Complaints and Unfair Trade Practices: An Empirical Study of Ontario’s Business Practices Act. University of Western Ontario Law Review, 24, 83.

Sand, M. A., \& Weisberg, J. (1966). Translating Sympathy for Deceived Consumers into Effective Programs for Protection. University of Pennsylvania Law Review, 114, 395.

Schmitz, A. J. (2013). Access to Consumer Remedies in the Squeaky Wheel System. Pepperdine Law Review, 39, $279-366$.

Schurink, W., Fouché, C. B., De Vos, A. S., Strydom, H., \& Delport, C. S. L. (2011). Research at Grass Roots: For the Social Sciences and Human Service Professions. Pretoria: Van Schaik.

Spiller, P., \& Tokeley, K. (2010). Individual Consumer Redress. In: G. Howells, I. Ramsay, T. Wilhelmsson, \& D. Kraft (Eds.), Handbook of Research on International Consumer Law (Chap. 16, p. 482). Cheltenham: Edward Elgar Publishing.

Stuhmcke, A. (2002). The Rise of the Australian Telecommunications Industry Ombudsman. Telecommunications Policy, 26, 69-85.

Northwestern University School of Law (1975). Consumer Protection-New Hope Following Failure of Civil and Criminal Remedies. Journal of Criminal Law and Criminology, 66, 271-285.

van Aggelen, J. (2013). Review of “The Access of Individuals to International Justice”. Leiden Journal of International Law, 26, 219-222.

Vidmar, N. (1988). Seeking Justice: An Empirical Map of Consumer Problems and Consumer Responses in Canada. Osgoode Hall Law Journal, 26, 757-796.

Watch, R. (2006). Introduction to Competition Law: A Sine qua Non to a Liberalised Economy. 1-31.

WB (2013). World Bank Economic Report: Nigeria, No. 1, May 2013.

Willet, C., \& Oughton, D. (2010). Consumer Protection. In M. Furmston, and J. Chuah (Eds.), Commercial and Consumer Law. Harlow: Pearson Education Ltd. 
Yuthayotin, S. (2015a). Access to Justice: A Goal for Consumer Protection. In S. Yuthayotin (Ed.), Access to Justice in Transnational B2C E-Commerce (pp. 37-64). Cham: Springer International Publishing. http://dx.doi.org/10.1007/978-3-319-11131-5_3

Yuthayotin, S. (2015b). Procedural Mechanisms for Achieving Access to Justice. In S. Yuthayotin (Ed.), Access to Justice in Transnational B2C E-Commerce (pp. 177-212). Cham: Springer International Publishing. http://dx.doi.org/10.1007/978-3-319-11131-5_6 